\title{
Article \\ Release of Bisphenol A from Pit and Fissure Sealants According to Different $\mathrm{pH}$ Conditions
}

\author{
Eun-Deok Jo ${ }^{1}$, Sang-Bae Lee ${ }^{1}\left(\mathbb{D}\right.$, Chung-Min Kang ${ }^{2} \mathbb{D}$, Kwang-Mahn Kim ${ }^{1, * \mathbb{D}}$ and Jae-Sung Kwon ${ }^{1,3, * \mathbb{D}}$ \\ 1 Department and Research Institute of Dental Biomaterials and Bioengineering, College of Dentistry, \\ Yonsei University, Seoul 03722, Korea; jdpink@hanmail.net (E.-D.J.); ridm@yuhs.ac (S.-B.L.) \\ 2 Department of Pediatric Dentistry, College of Dentistry, Yonsei University, Seoul 03722, Korea; \\ kangcm@yuhs.ac \\ 3 BK21 FOUR Project, College of Dentistry, Yonsei University, Seoul 03722, Korea \\ * Correspondence: kmkim@yuhs.ac (K.-M.K.); jkwon@yuhs.ac (J.-S.K.); Tel.: +82-2-2228-3082 (K.-M.K.); \\ $+82-2-2228-3081$ (J.-S.K.)
}

Citation: Jo, E.-D.; Lee, S.-B.; Kang, C.-M.; Kim, K.-M.; Kwon, J.-S. Release of Bisphenol A from Pit and Fissure Sealants According to Different $\mathrm{pH}$ Conditions. Polymers 2022, 14, 37. https://doi.org/ $10.3390 /$ polym 14010037

Academic Editors: Farid Bakir and Navideh Abbasnezhad

Received: 25 November 2021 Accepted: 15 December 2021 Published: 23 December 2021

Publisher's Note: MDPI stays neutral with regard to jurisdictional claims in published maps and institutional affiliations.

Copyright: (c) 2021 by the authors. Licensee MDPI, Basel, Switzerland. This article is an open access article distributed under the terms and conditions of the Creative Commons Attribution (CC BY) license (https:// creativecommons.org/licenses/by/ $4.0 /)$.

\begin{abstract}
Changes in intraoral $\mathrm{pH}$ can cause changes in the chemical decomposition and surface properties of treated resin-based pits and fissure sealants (sealant). The purpose of this study is to evaluate the release of bisphenol A (BPA) from sealants under three different $\mathrm{pH}$ conditions over time. The test specimen was applied with 6 sealants $5 \mathrm{mg}$ each on a glass plate $(10 \times 10 \mathrm{~mm})$ and photopolymerized. The samples were immersed for $10 \mathrm{~min}, 1 \mathrm{~h}$, and $24 \mathrm{~h}$ in solutions of $\mathrm{pH}$ 3.0, 6.5, and 10.0 at $37^{\circ} \mathrm{C}$. BPA release was measured using a gas chromatography-mass spectrometer. A statistical analysis was performed by two-way ANOVA and one-way ANOVA to verify the effect of $\mathrm{pH}$ conditions and time on BPA release. The BPA concentration in the $\mathrm{pH} 3.0$ group was higher at all points than with $\mathrm{pH} 6.5$ and $\mathrm{pH} 10.0(p<0.05)$, and gradually increased over time $(p<0.05)$. As a result, it was confirmed that low $\mathrm{pH}$ negatively influences BPA release. Therefore, frequent exposure to low $\mathrm{pH}$ due to the consumption of various beverages after sealant treatment can negatively affect the sealant's chemical stability in the oral cavity.
\end{abstract}

Keywords: pit and fissure sealant; dental biomaterials; $\mathrm{pH}$; bisphenol A

\section{Introduction}

Dental pits and fissure sealants (sealant) are among the most commonly used materials to prevent tooth decay in children and adolescents [1-4]. However, sealants consist mainly of bis-GMA, bis-EMA, and bis-EMA monomers containing bisphenol A (BPA, CAS number: 80-05-7) $[5,6]$. That is, BPA is a precursor to monomers, which are organic substrates. BPA may exist as an impurity if chemical synthesis is not completed in the process of preparing the dental sealant based on monomers such as bis-GMA, or if the synthesis reset does not reach stoichiometric completion. In 1996, Olea et al. [5] reported that leakage of BPA from dental sealants to patient saliva increased concerns about the potential estrogenicity of dental materials. Another study by Fung et al. [7] argued that BPA released from tooth sealants might be absorbed or present in undetectable amounts in the systemic circulation. BPA was recognized in the 1930s as an endocrine-disrupting chemical (EDC) that mimics estrogen and changes hormone function [8]. Since the 1990s, similar effects of BPA on female hormones have been reported [9-11]. In addition, the adverse effects of BPA on the human body include disorders in central nervous system development and function, reproductive function, thyroid hormone function, and fetal oocyte meiosis function [12,13]. In addition, BPA can be more harmful to children and adolescents, who are the main subjects of sealant treatments [14]. One study found that early exposure to BPA accelerates the onset of puberty in female mice but reduces reproductive parameters [13]. In another study, the concentration of BPA was 10 times higher than that of adults in neonatal rats when oral administration of biologically active BPA was detected [15]. Because of this, infants and toddlers are susceptible to BPA exposure, so the use of products containing BPA 
for infants and toddlers is completely prohibited in the United States, the United Kingdom, and Korea [16].

BPA is formed by the decomposition of bis-GMA or bis-EMA and is released in various concentrations depending on the chemical or mechanical processes occurring in the oral cavity [17]. Drinking various beverages causes changes in the $\mathrm{pH}$ of the saliva in the mouth [18]. Recently, the consumption of carbonated drinks, fruit juices, and sports drinks by children and adolescents has increased due to improved living standards and the spread of eating-out culture $[19,20]$. Beverages which are widely consumed have different $\mathrm{pH}$ levels. Reddy et al. [21] classified the $\mathrm{pH}$ of 379 beverages in one state of the USA, finding that $93 \%$ (354 of 379) were below $\mathrm{pH}$ 4.0. These acidic foods or beverages are essential factors that affect the durability and lifespan of resin recovery. Low acidity may cause deterioration of the physical properties and chemical deterioration of the restored material [22]. As a result of examining the difference in residual monomer leakage according to acidity and immersion time for three types of composite resins, it was reported that the outflow increased significantly as the immersion time increased at $\mathrm{pH} 4$ [23].

Therefore, it is essential to consider the effect of $\mathrm{pH}$ levels on oral repair materials. However, there have been few studies on BPA release according to $\mathrm{pH}$ and time in dental sealants. In addition, the concentrations of BPA released from previously reported dental sealants are wide-ranging, making it difficult to draw comparisons. The reason for this is that the study method differs from the actual method of clinical sealant treatment and the amount of sealant used. Therefore, in this study, a research method was designed by investigating the amount of sealant used in clinical practice. The purpose of this study is to evaluate the release of bisphenol A (BPA) from sealants in 3 conditions of $\mathrm{pH}$ over time.

\section{Materials and Methods}

\subsection{Materials}

The sealants used in this study are shown in Table 1. Sealants used in this study were randomly selected from a resin-based light-cured type used commercially in clinical practice. The $\mathrm{pH}$ conditions of the solvent for immersing the specimens were classified into three levels: $\mathrm{pH}$ 3.0, $\mathrm{pH}$ 6.5, and $\mathrm{pH}$ 10.0. Step-by-step $\mathrm{pH}$ levels were measured and adjusted using a commercial $\mathrm{pH}$ meter (ORION ${ }^{\mathrm{TM}}$ Star A211, Thermo Scientific, Waltham, MA, USA). Before all procedures, the $\mathrm{pH}$ meter was calibrated using a $\mathrm{pH}$ buffer (Thermo Scientific $^{\mathrm{TM}}$ Orion $\left.^{\mathrm{TM}} \mathrm{pH} 4.01,7.00,10.01\right)$ for accurate reproduction. The $\mathrm{pH} 3.0$ level was prepared by mixing lactic acid (CAS No. 50-21-5) in distilled water (JW-pharma. Co., Seoul, Korea), while the $\mathrm{pH} 10.0$ level was prepared using sodium hydroxide solution $(\mathrm{NaOH}$, CAS No. 1310-73-2). For the pH 6.5 level, sterile distilled water was used, which was opened immediately before the test and used after checking the $\mathrm{pH}$. The prepared $\mathrm{pH}$ solutions were stored under air-tight conditions by packing them with a Press'n Seal ${ }^{\circledR}$ (GLAD, Oakland, CA, USA).

Table 1. The compositions of the sealants were tested, according to the manufacturers' information.

\begin{tabular}{|c|c|c|c|}
\hline & Sealant & Composition (\% by $\mathrm{Wt}$ ) & Manufacturer \\
\hline $\mathrm{A}$ & Clinpro $^{\mathrm{TM}}$ & $\begin{array}{l}\text { bis-GMA * }(40 \sim 50) \text {, } \\
\text { TEGDMA }(40 \sim 50)\end{array}$ & 3M ESPE, Seefeld, Germany \\
\hline $\mathrm{B}$ & Eco-s ${ }^{\circledR}$ & $\begin{array}{l}\text { bis-GMA * (50 55), } \\
\text { TEGDMA }(35 \sim 40)\end{array}$ & Vericom, Gyeonggi, Korea \\
\hline $\mathrm{C}$ & UltraSeal XT ${ }^{\circledR}$ plus & $\begin{array}{c}\text { bis-GMA* (not revealed), } \\
\text { TEGDMA }(10 \sim 25) \\
\text { DUDMA }(2.5 \sim 10)\end{array}$ & $\begin{array}{l}\text { Ultradent Products, } \\
\text { South Jordan, UT, USA }\end{array}$ \\
\hline $\mathrm{D}$ & Charmseal $^{\circledR}$ & $\begin{array}{l}\text { bis-GMA * (not revealed), } \\
\text { TEGDMA, UDMA }\end{array}$ & DenKist, Gyeonggi, Korea \\
\hline
\end{tabular}


Table 1. Cont.

\begin{tabular}{cccc}
\hline & Sealant & Composition (\% by Wt) & Manufacturer \\
\hline E & Seal-it $^{\circledR}$ & $\begin{array}{c}\text { bis-EMA * }(30 \sim 50), \\
\text { TEGDMA }(20 \sim 30)\end{array}$ & Spident, Incheon, Korea \\
\hline F & FORTIFY ${ }^{\circledR}$ & $\begin{array}{c}\text { bis-DMA * (5 10), } \\
\text { UDMA (30 50) }\end{array}$ & Bisco, Schaumburg, IL, USA \\
$\begin{array}{l}\text { * BPA-based monomers, bis-GMA (bisphenol A glycidyldimethacrylate), TEGDMA (triethyleneglycol dimethacry- } \\
\text { late), DUDMA (diurethane dimethacrylate), UDMA (urethane dimethacrylate), bis-EMA (bisphenol A ethoxylate- } \\
\text { dimethacrylate), bis-DMA (bisphenol A dimethacrylate). }\end{array}$
\end{tabular}

\subsection{Methods}

\subsubsection{Pre-Investigation on the Amount of Sealant}

The actual amount of sealant used in clinical practice in pit and fissure sealant treatments was investigated. Five dental hygienists with more than one year of clinical experience applied sealant to a tooth model, i.e., the second molar. The difference in mass before and after applying the sealant was analyzed. It was found that the average amount of total sealant was $4.90 \mathrm{mg}$ (Table 2). Therefore, $5 \mathrm{mg}$ of sealant was used in the BPA release test in this study.

Table 2. Amount of sealant applied to the first molar models.

\begin{tabular}{ccccc}
\hline \multirow{2}{*}{ No. } & $\boldsymbol{N}$ & \multicolumn{2}{c}{ Amount of Sealant (mg) } & \multirow{2}{*}{ F/ $\boldsymbol{p}$} \\
\cline { 3 - 4 } & & $\mathbf{M} \pm \mathbf{S D}$ & Min-Max & \\
\hline 1 & 5 & $4.47 \pm 0.30$ & $4.11-4.85$ \\
2 & 5 & $5.92 \pm 0.70$ & $4.69-6.47$ & \\
3 & 5 & $4.71 \pm 0.71$ & $4.06-6.01$ & \multirow{2}{*}{$4.812 / 0.007$} \\
4 & 5 & $4.38 \pm 0.39$ & $4.00-4.98$ & \\
5 & 5 & $5.03 \pm 0.70$ & $4.07-5.77$ & \\
\hline Total & 25 & $4.90 \pm 0.79$ & $4.00-6.47$ \\
\hline
\end{tabular}

\subsubsection{Sealant Specimens for BPA Release Test}

$5 \mathrm{mg}$ of sealant was applied to the glass plate $(10 \mathrm{~mm} \times 10 \mathrm{~mm})$. Sealant specimens were light-cured at the same distance, according to the manufacturer's instructions. The total number of samples for the BPA release test was 270; five of each of the six sealants (Table 3).

Table 3. Sealant specimens for BPA release test.

\begin{tabular}{|c|c|c|c|c|}
\hline \multirow{2}{*}{ Conditions } & \multirow{2}{*}{$N$} & \multicolumn{3}{|c|}{ Sealant Specimens (ea) } \\
\hline & & $10 \mathrm{~min}$ & $1 \mathrm{~h}$ & $24 \mathrm{~h}$ \\
\hline $\mathrm{pH} 3.0$ & 90 & $30(6 \mathrm{~S} \times 5$ each $)$ & $30(6 \mathrm{~S} \times 5$ each $)$ & $30(6 \mathrm{~S} \times 5$ each $)$ \\
\hline $\mathrm{pH} 6.5$ & 90 & $30(6 \mathrm{~S} \times 5$ each $)$ & $30(6 \mathrm{~S} \times 5$ each $)$ & $30(6 \mathrm{~S} \times 5$ each $)$ \\
\hline pH 10.0 & 90 & $30(6 \mathrm{~S} \times 5$ each $)$ & $30(6 \mathrm{~S} \times 5$ each $)$ & $30(6 \mathrm{~S} \times 5$ each $)$ \\
\hline Total & 270 & 90 & 90 & 90 \\
\hline
\end{tabular}

\subsubsection{Procedure of BPA Release Test}

First, the sealant $(5 \mathrm{mg})$ was applied and photopolymerized to a glass plate $(10 \times 10 \mathrm{~mm})$ to prepare each specimen. Next, the specimens were submerged completely in $2 \mathrm{~mL}$ solvent in a $15 \mathrm{~mL}$ conical tube. Next, these were immersed in an incubator shaker (Lab Companion SI-600, Seoul, Korea) at $37^{\circ} \mathrm{C}$ for three time periods (10 min, $1 \mathrm{~h}, 24 \mathrm{~h}$ ). Immediately after the immersion time, the specimens were removed from the conical tube, cooled in a freezer and then freeze-dried for more than $12 \mathrm{~h}$ using a freeze dryer (Ilshin Lab Co., Ltd., Yangju-si, 
Korea). BPA detection was analyzed by gas chromatography and a mass spectrometer (GCMS; Agilent Technologies 7820A GC and 5977E MSD system, Palo Alto, CA, USA). Finally, $2 \mathrm{~mL}$ pure methanol ( $\geq 99.99 \%$ ) was mixed in the conical tubes for GC-MS analysis. These were transferred to $1.5 \mathrm{~mL}$ vials (Agilent, Palo Alto, CA, USA) and used by GC-MS.

\subsubsection{Conditions and Calibration of GC/MS}

The conditions of the GC-MS instrument for BPA detection are shown in Table 4. First, the molecular weight of BPA was confirmed by performing a qualitative analysis of standards (SCAN) according to the four BPA standard concentrations (10, 20, 50, $100 \mathrm{ppm}$ ). Then, to evaluate the amount of BPA detected for each sample, a quantitative analysis, i.e., selecting and measuring specific ions (selected ion monitoring, SIM), was performed. The standard material of BPA was prepared by mixing $1 \mathrm{~g}$ of bisphenol A (CAS: 80-05-7) and $1000 \mathrm{mg} / \mathrm{L}$ of methanol ( $\geq 99.99 \%$ ) and then diluting with the same solvent to $10,20,50$, and $100 \mathrm{ppm}$ each. These solutions were stored at $-18^{\circ} \mathrm{C}$. After GC-MS measurement of the samples, calibration was performed based on the standard concentration to obtain accurate BPA detection data. Figure 1 shows the calibration after GC-MS measurement of the standard samples. The resultant calibration functions had correlation coefficients $\left(R^{2}\right)$ ranging from 0.998 to 1.000 .

\subsection{Statistical Analysis}

First, data on BPA release were separately subjected to a two-way ANOVA ( $\mathrm{pH}$ level $\times$ immersion time) and Tukey's test. Additionally, one-way ANOVA was performed to compare the difference in BPA concentration according to the $\mathrm{pH}$ group and time. Significance was determined at the $p=0.05$ level.

Table 4. Instrument conditions of GC-MS for BPA detection.

\begin{tabular}{|c|c|c|c|c|}
\hline & \multicolumn{4}{|c|}{ Conditions } \\
\hline Column & \multicolumn{4}{|c|}{ HP-5ms Ultra Inert (30 m $250 \mu \mathrm{m} 0.25 \mu \mathrm{m})$} \\
\hline \multirow{7}{*}{ Oven Temp. } & Unit & Rate $\left({ }^{\circ} \mathrm{C} / \mathrm{min}\right)$ & Temp. $\left({ }^{\circ} \mathrm{C}\right)$ & Hold (min) \\
\hline & Initial & - & 40 & 0 \\
\hline & Ramp1 & 5 & 50 & 0 \\
\hline & Ramp2 & 5 & 80 & 2 \\
\hline & Ramp3 & 10 & 120 & 5 \\
\hline & Ramp4 & 10 & 280 & 1 \\
\hline & Ramp5 & 10 & 320 & 0 \\
\hline Inlet Temp. & \multicolumn{4}{|c|}{$250{ }^{\circ} \mathrm{C}$} \\
\hline Injection Mode & \multicolumn{4}{|c|}{ splitless } \\
\hline Injection Vol. & \multicolumn{4}{|c|}{$1 \mu \mathrm{L}$} \\
\hline Carrier Gas & \multicolumn{4}{|c|}{ Helium } \\
\hline Carrier Flow & \multicolumn{4}{|c|}{$0.7 \mathrm{~mL} / \mathrm{min}$} \\
\hline Scan Parameters & \multicolumn{4}{|c|}{$40 \sim 615$} \\
\hline Sim Parameters & \multicolumn{4}{|c|}{ bisphenol A: 213.3, 119, 228, 214} \\
\hline
\end{tabular}


(a) \& $\left.x 10^{5}\right\rfloor y=2.067950 * x-15934.231189$

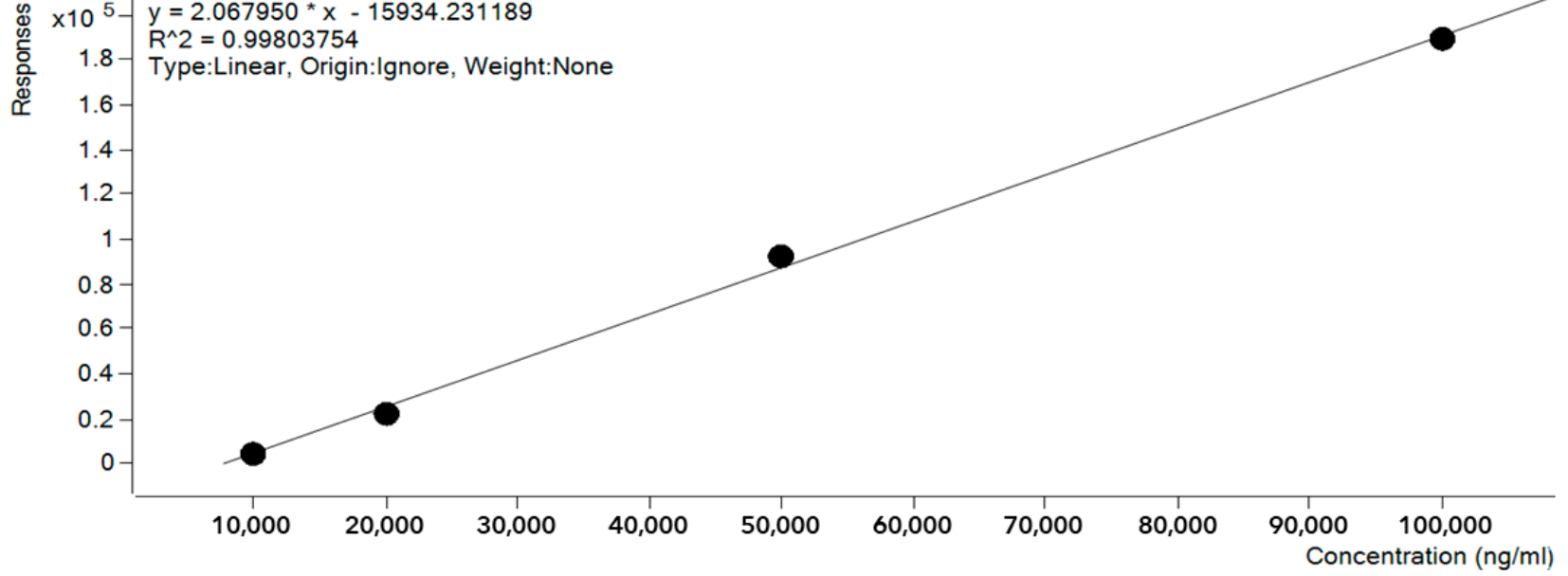

(b) BPA-10 ppm

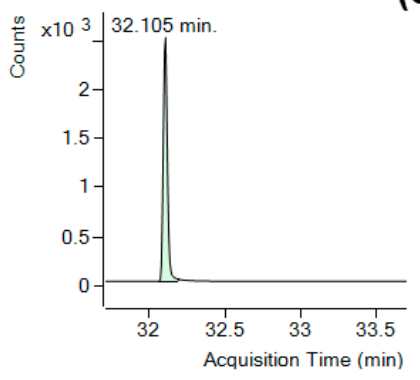

(c) $\mathrm{BPA}-20 \mathrm{ppm}$

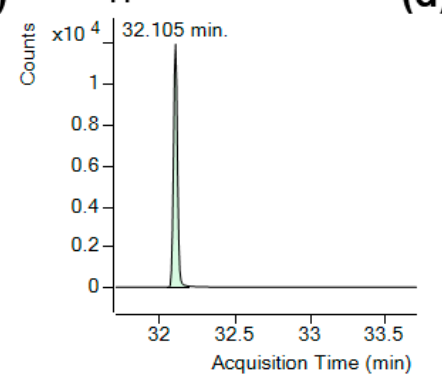

(d) BPA-50 ppm

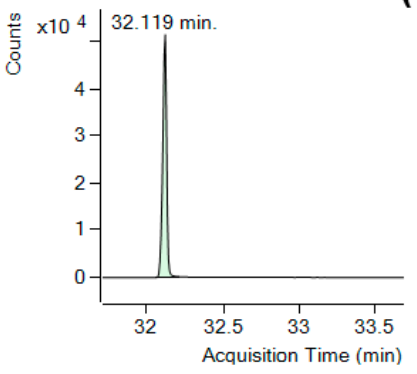

(e) BPA-100 ppm

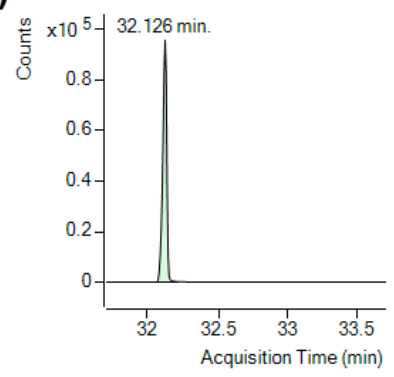

Figure 1. Calibration after GC-MS measurement of the standard samples: (a) Linear calibration of 4 samples, (b) Selected Ion (213.3) bisphenol A 10 ppm, (c) Selected Ion (213.3) bisphenol A 20 ppm, (d) Selected Ion (213.3) bisphenol A 50 ppm, (e) Selected Ion (213.3) bisphenol A 100 ppm.

\section{Results}

\subsection{The Difference in BPA Concentration (ppm) According to $\mathrm{pH}$ Levels and Time}

A comparison pf bisphenol A concentration (ppm) according to $\mathrm{pH}$ group and time is shown in Table 5. First, in the $\mathrm{pH} 3.0$ group, the BPA concentration was higher at $24 \mathrm{~h}$ $(2.14 \mathrm{ppm})$ than at $10 \mathrm{~min}(0.35 \mathrm{ppm})$ and $1 \mathrm{~h}(0.72 \mathrm{ppm})(\mathrm{F}=11.196, p<0.05)$. Similarly, in the $\mathrm{pH} 6.5$ and $\mathrm{pH} 10.0$ groups, the BPA concentration was higher at $24 \mathrm{~h}(0.28,0.52 \mathrm{ppm})$ than at $10 \mathrm{~min}(0.09,0.09 \mathrm{ppm})$ or $1 \mathrm{~h}(0.18,0.25 \mathrm{ppm})(\mathrm{F}=5.303,9.189, p<0.05)$. Next, regarding our comparison by time point, there were significant differences, i.e., the BPA concentration was higher at $\mathrm{pH} 3.0$ than at $\mathrm{pH} 6.5$ or $\mathrm{pH} 10.0$ at all time points. At $10 \mathrm{~min}$, the BPA concentration was higher at $\mathrm{pH} 3.0(0.35 \mathrm{ppm})$ than $\mathrm{pH} 6.5(0.09 \mathrm{ppm})$ or $\mathrm{pH} 10.0$ $(0.09 \mathrm{ppm})(\mathrm{F}=15.492, p<0.05)$. Similarly, at $1 \mathrm{~h}$ and $24 \mathrm{~h}$, the BPA concentration was higher at $\mathrm{pH} 3.0(0.72,2.14 \mathrm{ppm})$ than at $\mathrm{pH} 6.5(0.18,0.28 \mathrm{ppm})$ or $\mathrm{pH} 10.0(0.25,0.52 \mathrm{ppm})$ $(\mathrm{F}=11.518,13.158, p<0.05)$.

Differences in BPA concentration (ppm) according to each factor are shown in Figure 2. First, as a result of comparing BPA emission according to $\mathrm{pH}$ levels (a), the $\mathrm{pH} 3.0$ group was 5.7 times and 3.7 times higher than the $\mathrm{pH} 6.5$ group and $\mathrm{pH} 10.0$ group, respectively $(p<0.05)$. Next, as a result of comparing the release of BPA over time (b), $24 \mathrm{~h}$ was 5.5 times and 2.6 times higher than $10 \mathrm{~min}$ and $1 \mathrm{~h}$, respectively $(p<0.05)$. 
Table 5. The difference in BPA concentration (ppm) according to $\mathrm{pH}$ levels and time.

\begin{tabular}{|c|c|c|c|c|c|}
\hline \multirow[b]{2}{*}{ Group } & \multicolumn{4}{|c|}{ BPA (ppm) } & \multirow[b]{2}{*}{$\mathrm{F} / p$} \\
\hline & $\begin{array}{l}10 \min \\
\mathrm{M}(\mathrm{SD})\end{array}$ & $\begin{array}{c}1 \mathrm{~h} \\
\mathrm{M}(\mathrm{SD})\end{array}$ & $\begin{array}{c}24 \mathrm{~h} \\
\mathrm{M}(\mathrm{SD})\end{array}$ & (Min-Max) & \\
\hline $\mathrm{pH} 3.0$ & $0.35(0.30)^{b, A}$ & $0.72(0.73)^{b, A}$ & $2.14(2.55)^{a, A}$ & $(0.07-7.74)$ & 11.196 * \\
\hline pH 6.5 & $0.09(0.14)^{b, B}$ & $\begin{array}{c}0.18(0.23) \\
a b, B\end{array}$ & $0.28(0.28)^{a, B}$ & $(<0.01-1.06)$ & $5.303 *$ \\
\hline pH 10.0 & $0.09(0.13)^{b, B}$ & $0.25(0.31)^{b, B}$ & $0.52(0.60)^{a, B}$ & $(<0.01-2.81)$ & $9.189 *$ \\
\hline $\mathrm{F} / p$ & $15.492 *$ & 11.518 * & $13.158^{*}$ & & \\
\hline Source & & & $\mathrm{F} / p$ & & \\
\hline $\mathrm{pH}$ & & & $24.440 *$ & & \\
\hline Time & & & 18.153 * & & \\
\hline $\mathrm{pH}^{*}$ Time & & & 7.361 * & & \\
\hline
\end{tabular}

$\overline{a, b}$ Post-analysis by Tukey within a group $(a>b),{ }^{A, B}$ Post-analysis by Tukey in a time point $(\mathrm{A}>B) * p<0.05$.

(a)

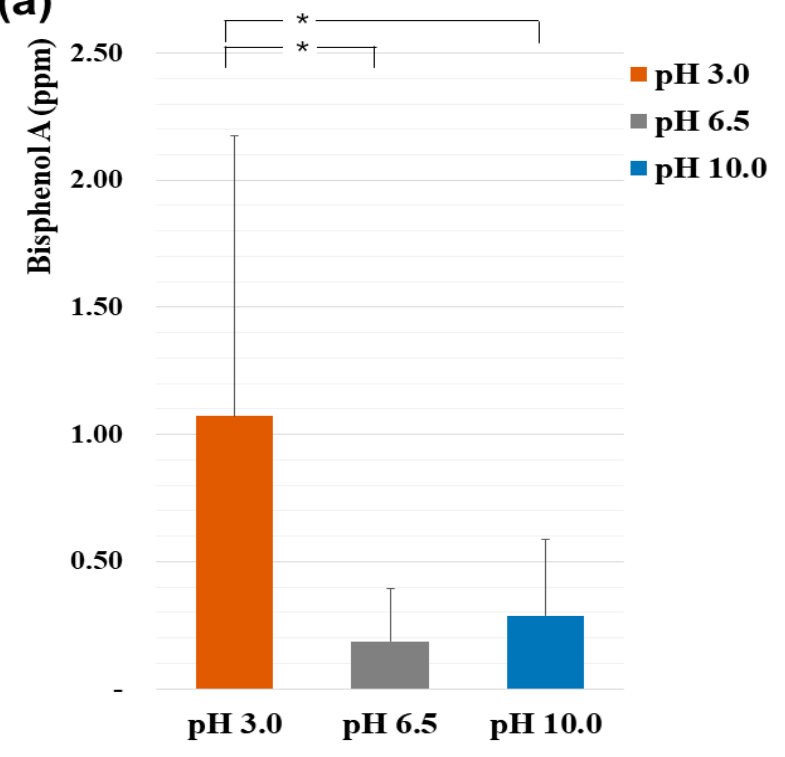

(b)

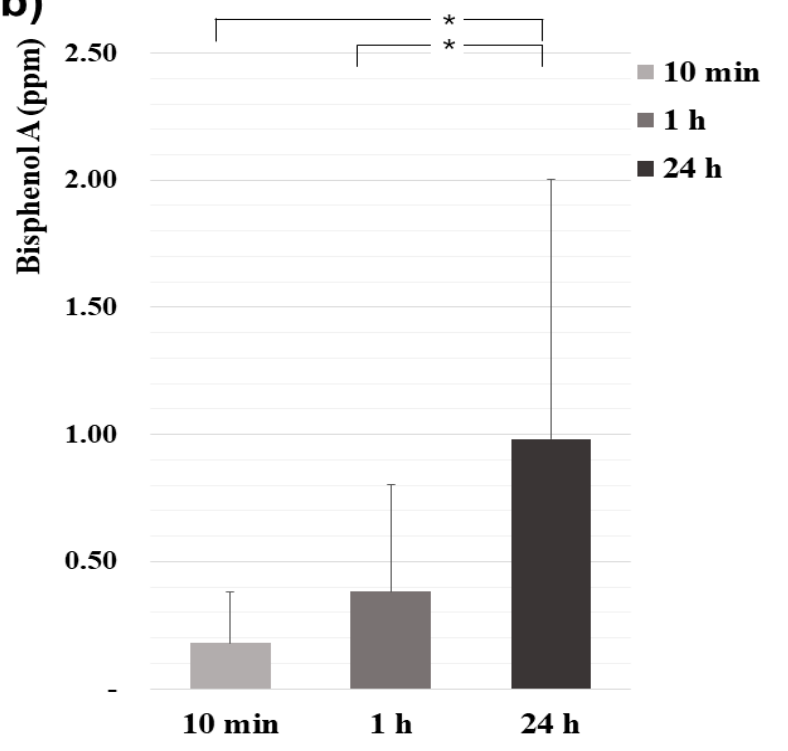

Figure 2. Differences in BPA concentration (ppm) according to each factor: (a) BPA release according to $\mathrm{pH}$ levels $\left({ }^{*} p<0.05\right)$; (b) BPA release according to time $\left({ }^{*} p<0.05\right)$.

\subsection{Comparison of BPA Concentration According to $\mathrm{pH}$ Level and Time of Each Sealant}

Table 6 and Figure 3 show a comparison of BPA concentrations of each sealant product according to $\mathrm{pH}$ level and time. BPA was detected in all sealants under all conditions. In addition, in all sealants, the BPA concentration of the $\mathrm{pH} 3.0$ group was higher than in the $\mathrm{pH} 6.5$ and $\mathrm{pH} 10.0$ groups $(p<0.05)$. Finally, the BPA concentrations of all $\mathrm{pH}$ groups increased over time (within $24 \mathrm{~h} ; p<0.05$ ). 
Table 6. BPA concentration (ppm) according to $\mathrm{pH}$ levels and time of each sealant.

\begin{tabular}{|c|c|c|c|c|c|}
\hline & & \multicolumn{3}{|c|}{ Bisphenol A (ppm) } & \multirow[b]{2}{*}{$\mathrm{F} / p$} \\
\hline \multicolumn{2}{|c|}{ Sealants/Group } & $\begin{array}{l}10 \text { min } \\
M(S D)\end{array}$ & $\begin{array}{c}1 \mathrm{~h} \\
\mathrm{M}(\mathrm{SD})\end{array}$ & $\begin{array}{c}24 \mathrm{~h} \\
\mathrm{M}(\mathrm{SD})\end{array}$ & \\
\hline \multirow[t]{4}{*}{ A } & pH 3.0 & $0.58(0.10)^{b, A}$ & $1.65(0.47)^{a, A}$ & $2.09(0.48)^{a, A}$ & 19.638 * \\
\hline & $\mathrm{pH} 6.5$ & $0.26(0.05)^{c, B}$ & $0.40(0.07)^{b, B}$ & $0.62(0.08)^{a, A B}$ & 35.813 * \\
\hline & $\mathrm{pH} 10.0$ & $0.35(0.09)^{b, B}$ & $0.61(0.22)^{a b, B}$ & $1.36(0.87)^{a, B}$ & $5.049 *$ \\
\hline & $\mathrm{F} / p$ & $19.457 *$ & $24.396 *$ & $8.192 *$ & \\
\hline \multirow[t]{4}{*}{$\mathrm{B}$} & pH 3.0 & $0.09(0.07)^{b, A}$ & $1.67(0.42)^{b, A}$ & $6.93(0.95)^{a, A}$ & $145.406^{*}$ \\
\hline & pH 6.5 & $0.22(0.12)^{b, B}$ & $0.52(0.30)^{a b, B}$ & $0.67(0.24)^{a, B}$ & $4.019 *$ \\
\hline & $\mathrm{pH} 10.0$ & $0.11(0.05)^{b, B}$ & $0.65(0.30)^{a, B}$ & $0.90(0.24)^{a, B}$ & 16.704 * \\
\hline & $\mathrm{F} / p$ & $33.311 *$ & $16.905^{*}$ & $186.455^{*}$ & \\
\hline \multirow[t]{4}{*}{$\mathrm{C}$} & pH 3.0 & $0.11(0.01)^{b, A}$ & $0.16(0.01)^{b, A}$ & $0.28(0.05)^{a, A}$ & 42.419 * \\
\hline & pH 6.5 & $0.03(<01)^{c, B}$ & $0.06(<01)^{b, B}$ & $0.11(0.01)^{a, B}$ & 201.652 * \\
\hline & pH 10.0 & $0.04(0.01)^{c, B}$ & $0.07(0.02)^{b, B}$ & $0.12(0.01)^{a, B}$ & $64.039 *$ \\
\hline & $\mathrm{F} / p$ & $121.907^{*}$ & $97.903^{*}$ & 51.062 * & \\
\hline \multirow[t]{4}{*}{$\mathrm{D}$} & pH 3.0 & $0.21(0.02)^{b, A}$ & $0.38(0.25)^{a b, A}$ & $0.75(0.37)^{a, A}$ & $5.780 *$ \\
\hline & $\mathrm{pH} 6.5$ & $0.03(0.04)^{b, B}$ & $0.04(<01)^{b, B}$ & $0.19(0.12)^{a, B}$ & $8.322 *$ \\
\hline & $\mathrm{pH} 10.0$ & $0.03(0.01)^{b, B}$ & $0.04(0.04)^{b, B}$ & $0.33(0.06)^{a, B}$ & $61.164 *$ \\
\hline & $\mathrm{F} / p$ & $374.387^{*}$ & $8.902 *$ & $8.138^{*}$ & \\
\hline \multirow[t]{4}{*}{$\mathrm{E}$} & pH 3.0 & $0.25(0.10)^{b, A}$ & $0.25(0.10)^{b, A}$ & $2.52(0.98)^{a}, A$ & $4.188 *$ \\
\hline & pH 6.5 & $0.02(0.02)^{B}$ & $0.02(0.02)^{B}$ & $0.05(0.04) A B$ & 0.851 \\
\hline & pH 10.0 & $0.02(<01)^{B}$ & $0.04(0.02)^{B}$ & $0.34(0.30)^{B}$ & 2.462 \\
\hline & $\mathrm{F} / p$ & $26.069 *$ & $23.278^{*}$ & 4.292 * & \\
\hline \multirow[t]{4}{*}{$\mathrm{F}$} & pH 3.0 & $0.08(0.01)^{b, A}$ & $0.22(0.09)^{a, A}$ & $0.27(0.08)^{a, A}$ & 10.108 * \\
\hline & pH 6.5 & $0.02(<01)^{c, B}$ & $0.04(<01)^{b, B}$ & $0.07(<01)^{a, B}$ & 781.970 * \\
\hline & pH 10.0 & $0.02(0.01)^{c, B}$ & $0.05(0.02)^{b, B}$ & $0.09(0.01)^{a, B}$ & 49.230 * \\
\hline & $\mathrm{F} / p$ & $124.536^{*}$ & 17.505 * & $32.187^{*}$ & \\
\hline
\end{tabular}

A: Clinpro ${ }^{\mathrm{TM}}, \mathrm{B}: \mathrm{Eco}^{\circledR}{ }^{\circledR}, \mathrm{C}$ : UltraSeal XT ${ }^{\circledR}$ plus, D: Charmseal ${ }^{\circledR}$, E: Seal-it ${ }^{\circledR}$, F: FORTIFY ${ }^{\circledR} .{ }^{a, b}$ Post-analysis by Tukey within a group $(a>b),{ }^{A, B}$ Post-analysis by Tukey in a time point $(\mathrm{A}>B),{ }^{*} p<0.05$.

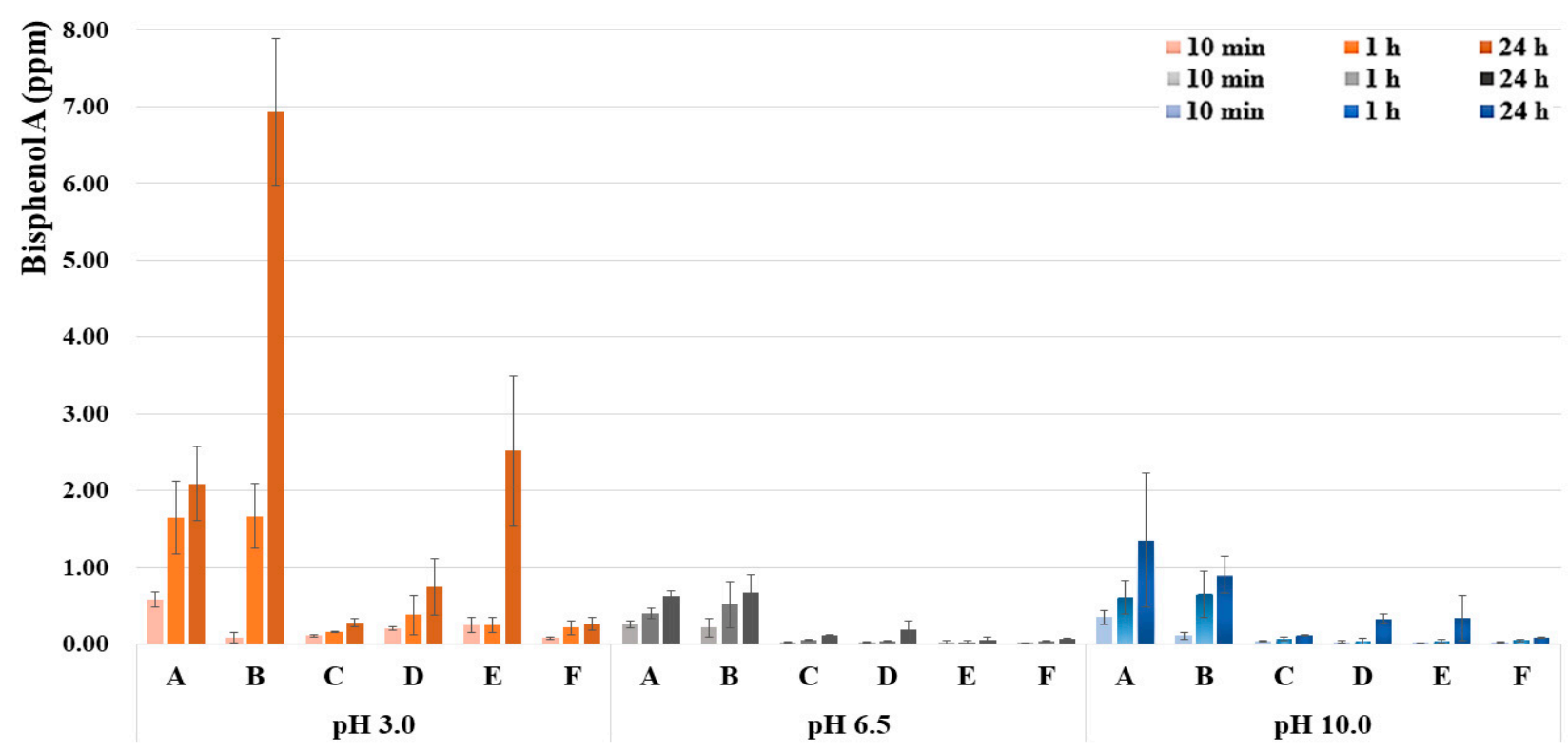

Figure 3. Comparison of BPA concentration ( $\mathrm{ppm})$ according to $\mathrm{pH}$ levels $(p<0.05)$ and time $(p<0.05)$ of each sealant (A: Clinpro ${ }^{\mathrm{TM}}, \mathrm{B}: \mathrm{Eco}{ }^{\circledR}, \mathrm{C}$ : UltraSeal XT ${ }^{\circledR}$ plus, D: Charmseal ${ }^{\circledR}$, E: Seal-it ${ }^{\circledR}$, F: FORTIFY ${ }^{\circledR}$ ). 


\section{Discussion}

Today, sealants are essential dental materials to prevent occlusal caries of teeth. However, there has been concern that BPA, an environmental hormone-disrupting substance, may be detected from these restorative materials. In addition, the beverages we consume have different $\mathrm{pH}$ levels, which alter the $\mathrm{pH}$ conditions in our mouths [18]. There has been concern that chemical and physical changes would occur to restorative materials if the oral $\mathrm{pH}$ changes after dental sealant treatment. Therefore, this study evaluated the difference in BPA release according to three $\mathrm{pH}$ conditions and immersion time after polymerized resin-based light-curing type dental sealant.

In this study, first, the amount of sealant used in the BPA release test was investigated. The reason for this was that the range of amounts of sealant applied in previous laboratory studies varied widely, and even the amount used in actual clinical practice was found to be different $[5,24-26]$. Therefore, five dental hygienists with more than one year of clinical experience applied five of the most widely used molar model sealants. As a result, it was confirmed that an average of $5 \mathrm{mg}$ of sealant was used per tooth $(p<0.05)$.

The results of this study confirmed that there was a significant difference in BPA emission according to $\mathrm{pH}$ level and immersion time $(p<0.05)$. First, the detected BPA concentration of the $\mathrm{pH} 3.0$ group was 5.7 times and 3.7 times higher than those of the $\mathrm{pH} 6.5$ and $\mathrm{pH} 10.0$ groups, respectively $(p<0.05)$. The pattern of these results was similarly confirmed in all six sealants. Similarly, several studies have reported that low $\mathrm{pH}$ beverages cause surface decomposition in resin composite materials [22,27]. In addition, in a survey of the effect of acidity on the chemical dissolution of composite resins, the outflow of monomers from a $\mathrm{pH} 4$ solution was significantly increased compared to a $\mathrm{pH}$ 7 solution [23]. Sealants are continuously exposed to various types of accommodation environments in the mouth. Hydrolysis reaction by water and expansion of the matrix surface by water absorption are the main causes of the chemical decomposition of resinbased restorations [28]. Components eluted from most composite resins are non-China compound monomers, but even crosslinked resins can cause hydrolysis. Figure 4a shows the hydrolysis step of bis-GMA [29]. Hydrolysis occurs when the OC $=\mathrm{O}$ bond between the acyl group of resin molecules and oxygen is broken [30]. At this time, since pores are generated, a decomposition product appears, yielding bisphenol A dimethacrylate (BADGE), 2,2-bis[4(2,3-hydroxypropoxy)phenyl]propane (bis-HPPP), BPA, etc. (Figure 4b) [31,32]. Perhaps the reason for this is that BPA is relatively unsoluble in water, but generally dissolves well in acetic acid, benzene, ethanol, etc.; Log Kow (Octanol-Water Partition Coefficient $)=3.32$. [33]. As such, acidity can accelerate the decomposition of the sealant of the resin substrate and destroy chemical stability.

The detected BPA concentration after $24 \mathrm{~h}$ were 5.5 times and 2.6 times higher than after $10 \mathrm{~min}$ and $1 \mathrm{~h}$, respectively $(p<0.05)$. At $\mathrm{pH} 3.0$, the BPA detection concentration was $0.35 \mathrm{ppm}(10 \mathrm{~min}), 0.75 \mathrm{ppm}(1 \mathrm{~h})$, and $2.14 \mathrm{ppm}(24 \mathrm{~h})$, showing higher values over time. Similar to the effect of $\mathrm{pH}$, the pattern of these results was confirmed in all six sealants. In other words, the longer acidic drinks stay in our mouths, the more BPA is detected over a 24-h period. In addition, BPA was detected at $\mathrm{pH} 6.5$ and $\mathrm{pH}$ 10.0, but levels were lower than at $\mathrm{pH} 3.0$, increasing in the order of $10 \mathrm{~min}(0.09 \mathrm{ppm}, 0.09 \mathrm{ppm}), 1 \mathrm{~h}(0.18 \mathrm{ppm}$, $0.24 \mathrm{ppm})$, and $24 \mathrm{~h}(0.28 \mathrm{ppm})$. After $24 \mathrm{~h}$, the BPA concentrations ( $\mathrm{pH} 0.3=2.14 \mathrm{ppm}$, $\mathrm{pH} 6.5=0.28 \mathrm{ppm}, \mathrm{pH} 10.0=0.52$ ) were lower than those reported by Pulgar and colleagues $(\mathrm{pH} 1.0=6.5 \mathrm{ppm}, \mathrm{Ph} 7.0=7.8 \mathrm{ppm})$ [25]. Our results were nonetheless similar those reported by Arenholt-Bindslev and colleagues (0.3-2.8 ppm) [24]. In 2000, MANABE and colleagues reported that when a sealant $(1 \mathrm{mg})$ was immersed in water for $24 \mathrm{~h}$, BPA was detected at 0.02-0.09 ppm, i.e., lower than $0.28 \mathrm{ppm}(\mathrm{pH} 6.5,24 \mathrm{~h})$ under similar conditions. [34]. The reason for this discrepancy is likely the different research methods used 20 years ago, such as the amount of sealant used, sealant type, and GC-MS equipment type and function improvements. 


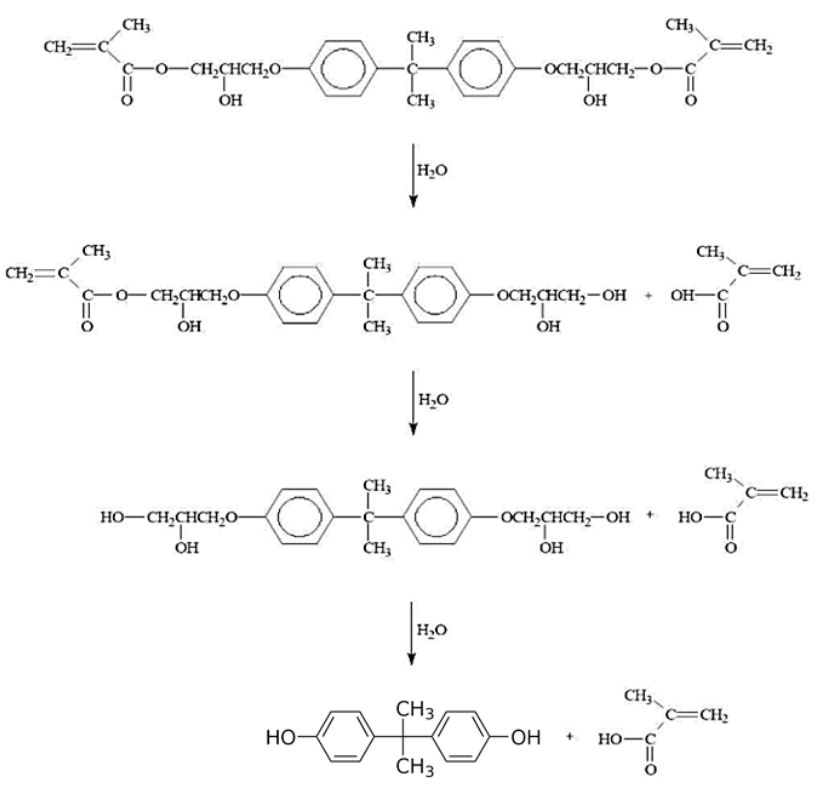

(a)
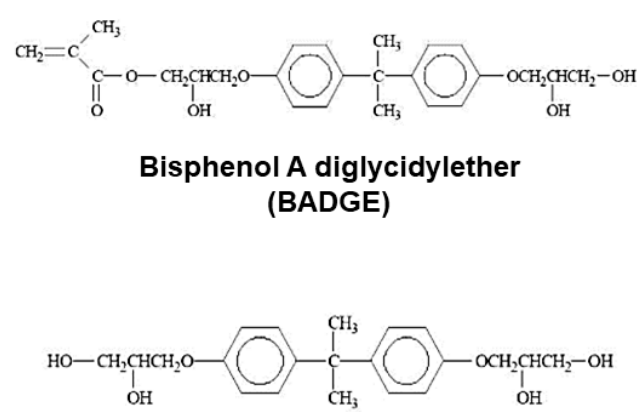

Bishydroxy-propoxy-phenyl-propane (Bis-HPPP)
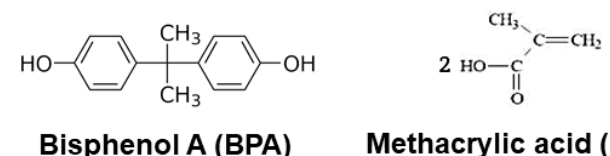

Methacrylic acid (MA)

(b)

Figure 4. Hydrolysis of resin component: (a) the hydrolysis step of bis-GMA [29]; (b) the types of decomposition products.

Finally, BPA was detected from all silanes under all conditions. Since various BPA concentrations were detected for each sealant, the minimum-maximum range of BPA according to $\mathrm{pH}$ level in the total sealant was in the order of $\mathrm{pH} 3(0.07 \sim 7.74 \mathrm{ppm}), \mathrm{pH}$ $10.0(<0.01 \sim 2.81 \mathrm{ppm})$, and $\mathrm{pH} 6.5(<0.01 \sim 1.06 \mathrm{ppm})$. The standard for BPA elution of plastic food containers is $0.05 \mathrm{ppm}$ in the EU, $0.6 \mathrm{ppm}$ in South Korea, and $2.5 \mathrm{ppm}$ in Japan [35-37]. The use of BPA in the manufacture of some baby products, including baby bottles, has been prohibited in the EU and South Korea. In addition, the use of BPA in manufacturing raw materials for cosmetics in the EU and South Korea has been prohibited. Comparing the range of BPA concentrations by $\mathrm{pH}$ group in this study, there may be concerns about the stability of dental sealants which are harmful to the human body. It was impossible to compare and analyze the amount of BPA detected by sealant type in this study. Previous research on the solubility of synthetic resins relative to acidity and time found that this factor was influenced by the kind of resin monomer and the composition of filler [38]. Perhaps the reason for this is that hydrophilicity varies depending on the type of resin monomer. The sealant used in this study was randomly selected. The types and configurations of resin substrates for each sealant cannot be accurately classified due to manufacturer confidentiality. Considering these points, future studies should consider comparisons of BPA detection by resin monomer type, and the development of BPA substitutes with endocrine toxicity.

The limitation of this study is that it was undertaken only with simple immersion without considering the immersion ability that affects the decomposition of the resin-based restorative. However, as an in vitro research method, there were two significant findings: (1) The oral temperature conditions and research methods were chosen to resemble actual conditions; and (2) Only differences due to $\mathrm{pH}$ were evaluated by controlling other influencing factors in the laboratory. Therefore, in future studies, it is suggested that a complementary experiment be applied which takes into account the $\mathrm{pH}$ circulation rate of saliva in the oral cavity.

\section{Conclusions}

Within the limitations of this study, it was confirmed that low $\mathrm{pH}$ is a factor that negatively influences BPA release. Therefore, frequent exposure to low $\mathrm{pH}$ due to the 
consumption of various beverages after sealant treatment can negatively affect the sealant's chemical stability in the oral cavity.

Author Contributions: Conceptualization, E.-D.J., J.-S.K., S.-B.L. and K.-M.K.; methodology, E.-D.J., J.-S.K., S.-B.L. and K.-M.K.; software, E.-D.J., J.-S.K., S.-B.L. and K.-M.K.; validation, E.-D.J., J.-S.K., S.-B.L. and K.-M.K.; formal analysis, E.-D.J. and K.-M.K.; investigation, E.-D.J. and K.-M.K.; resources, E.-D.J. and K.-M.K.; data curation, E.-D.J. and K.-M.K.; writing—original draft preparation, E.-D.J. and K.-M.K.; writing—review and editing, E.-D.J., J.-S.K., S.-B.L., C.-M.K. and K.-M.K.; visualization, E.-D.J., J.-S.K., S.-B.L. and K.-M.K.; supervision, J.-S.K., S.-B.L., C.-M.K. and K.-M.K.; project administration, E.-D.J., J.-S.K., S.-B.L. and K.-M.K. All authors have read and agreed to the published version of the manuscript.

Funding: This research received no external funding.

Institutional Review Board Statement: Not applicable.

Informed Consent Statement: Not applicable.

Data Availability Statement: The data presented in this study are available on request from the corresponding author.

Conflicts of Interest: The authors declare no conflict of interest.

\section{References}

1. Ferracane, J.L. Current trends in dental composites. Crit. Rev. Oral. Biol. Med. 1995, 6, 302-318. [CrossRef] [PubMed]

2. Ahovuo-Saloranta, A.; Forss, H.; Walsh, T.; Nordblad, A.; Mäkelä, M.; Worthington, H.V. Pit and fissure sealants for preventing dental decay in permanent teeth. Cochrane Database Syst. Rev. 2017. [CrossRef]

3. Azarpazhooh, A.; Main, P.A. Pit and fissure sealants in the prevention of dental caries in children and adolescents: A systematic review. J. Can. Dent. Assoc. 2008, 74, 171-178. [CrossRef]

4. Wiener, R.C.; Findley, P.A.; Shen, C.; Dwibedi, N.; Sambamoorthi, U. Acculturation and dental sealant use among US children. Community Dent. Oral Epidemiol. 2021. [CrossRef] [PubMed]

5. Olea, N.; Pulgar, R.; Pérez, P.; Olea-Serrano, F.; Rivas, A.; Novillo-Fertrell, A.; Pedraza, V.; Soto, A.M.; Sonnenschein, C. Estrogenicity of resin-based composites and sealants used in dentistry. Environ. Health Perspect. 1996, 104, 298-305. [CrossRef] [PubMed]

6. Schafer, T.E.; Lapp, C.A.; Hanes, C.M.; Lewis, J.B.; Wataha, J.C.; Schuster, G.S. Estrogenicity of bisphenol A and bisphenol A dimethacrylate in vitro. J. Biomed. Mater. Res. Off. J. Soc. Biomater. Jpn. Soc. Biomater. Aust. Soc. Biomater. 1999, 45, $192-197$. [CrossRef]

7. Fung, E.Y.; Ewoldsen, N.O.; Germain, H.A.S., Jr.; Marx, D.B.; Miaw, C.-L.; Siew, C.; Chou, H.-N.; Gruninger, S.E.; Meyer, D.M. Pharmacokinetics of bisphenol A released from a dental sealant. J. Am. Dent. Assoc. 2000, 131, 51-58. [CrossRef]

8. Vogel, S.A. The politics of plastics: The making and unmaking of bisphenol a "safety". Am. J. Public Health 2009, 99, S559-S566. [CrossRef]

9. Hamid, A.; Hume, W.R. A study of component release from resin pit and fissure sealants in vitro. Dent. Mater. 1997, 13, 98-102. [CrossRef]

10. Moriyama, K.; Tagami, T.; Akamizu, T.; Usui, T.; Saijo, M.; Kanamoto, N.; Hataya, Y.; Shimatsu, A.; Kuzuya, H.; Nakao, K. Thyroid hormone action is disrupted by bisphenol A as an antagonist. J. Clin. Endocrinol. Metab. 2002, 87, 5185-5190. [CrossRef] [PubMed]

11. Maffini, M.V.; Rubin, B.S.; Sonnenschein, C.; Soto, A.M. Endocrine disruptors and reproductive health: The case of bisphenol-A. Mol. Cell. Endocrinol. 2006, 254, 179-186. [CrossRef]

12. Chapin, R.E.; Adams, J.; Boekelheide, K.; Gray, L.E., Jr.; Hayward, S.W.; Lees, P.S.; McIntyre, B.S.; Portier, K.M.; Schnorr, T.M.; Selevan, S.G. NTP-CERHR expert panel report on the reproductive and developmental toxicity of bisphenol A. Birth Defects Res. Part B Dev. Reprod. Toxicol. 2008, 83, 157-395. [CrossRef] [PubMed]

13. Nah, W.H.; Park, M.J.; Gye, M.C. Effects of early prepubertal exposure to bisphenol A on the onset of puberty, ovarian weights, and estrous cycle in female mice. Clin. Exp. Reprod. Med. 2011, 38, 75. [CrossRef]

14. Hunt, P.A.; Susiarjo, M.; Rubio, C.; Hassold, T.J. The bisphenol A experience: A primer for the analysis of environmental effects on mammalian reproduction. Biol. Reprod. 2009, 81, 807-813. [CrossRef]

15. Taylor, J.A.; Welshons, W.V.; Vom Saal, F.S. No effect of route of exposure (oral; subcutaneous injection) on plasma bisphenol A throughout $24 \mathrm{~h}$ after administration in neonatal female mice. Reprod. Toxicol. 2008, 25, 169-176. [CrossRef]

16. Braun, J.M.; Kalkbrenner, A.E.; Calafat, A.M.; Yolton, K.; Ye, X.; Dietrich, K.N.; Lanphear, B.P. Impact of early-life bisphenol A exposure on behavior and executive function in children. Pediatrics 2011, 128, 873-882. [CrossRef] [PubMed]

17. Lopes-Rocha, L.; Ribeiro-Goncalves, L.; Henriques, B.; Ozcan, M.; Tiritan, M.E.; Souza, J.C.M. An integrative review on the toxicity of Bisphenol A (BPA) released from resin composites used in dentistry. J. Biomed. Mater. Res. B Appl. Biomater. 2021, 109, 1942-1952. [CrossRef] [PubMed] 
18. Pachori, A.; Kambalimath, H.; Maran, S.; Niranjan, B.; Bhambhani, G.; Malhotra, G. Evaluation of changes in salivary pH after intake of different eatables and beverages in children at different time intervals. Int. J. Clin. Pediatric Dent. 2018, 11, 177. [CrossRef]

19. Nielsen, S.J.; Popkin, B.M. Changes in beverage intake between 1977 and 2001. Am. J. Prev. Med. 2004, 27, 205-210. [CrossRef]

20. Storey, M.L.; Forshee, R.A.; Anderson, P.A. Beverage consumption in the US population. J. Am. Diet. Assoc. 2006, 106, 1992-2000. [CrossRef]

21. Reddy, A.; Norris, D.F.; Momeni, S.S.; Waldo, B.; Ruby, J.D. The pH of beverages in the United States. J. Am. Dent. Assoc. 2016, 147, 255-263. [CrossRef] [PubMed]

22. Han, L.; Okamoto, A.; Fukushima, M.; Okiji, T. Evaluation of flowable resin composite surfaces eroded by acidic and alcoholic drinks. Dent. Mater. J. 2008, 27, 455-465. [CrossRef]

23. Jeon, C.-M.; Yoo, H.-M.; Kwon, H.-C. Effect of $\mathrm{pH}$ and storage time on the elution of residual monomers from polymerized composite resins. J. Korean Acad. Conserv. Dent. 2004, 29, 249-266. [CrossRef]

24. Arenholt-Bindslev, D.; Breinholt, V.; Preiss, A.; Schmalz, G. Time-related bisphenol-A content and estrogenic activity in saliva samples collected in relation to placement of fissure sealants. Clin. Oral Investig. 1999, 3, 120-125. [CrossRef]

25. Pulgar, R.; Olea-Serrano, M.F.; Novillo-Fertrell, A.; Rivas, A.; Pazos, P.; Pedraza, V.; Navajas, J.-M.; Olea, N. Determination of bisphenol A and related aromatic compounds released from bis-GMA-based composites and sealants by high performance liquid chromatography. Environ. Health Perspect. 2000, 108, 21-27. [CrossRef]

26. Gruninger, S.; Tiba, A.; Vinh, R. Bisphenol A released from resin based dental sealants. ADA Prof. Prod. Rev. 2015, 10, 8-16.

27. ABU-BAKR, N.H.; HAN, L.; OKAMOTO, A.; IWAKU, M. Effect of Alcoholic and Low-pH Soft Drinks on Fluoride Release from Compomer. J. Esthet. Restor. Dent. 2000, 12, 97-104. [CrossRef] [PubMed]

28. Øysæd, H.; Ruyter, I.E. Water Sorption and Filler Characteristics of Composites for Use in Posterior Teeth. J. Dent. Res. 1986, 65, 1315-1318. [CrossRef]

29. Finer, Y.; Santerre, J.P. Biodegradation of a dental composite by esterases: Dependence on enzyme concentration and specificity. J. Biomater. Sci. Polym. Ed. 2003, 14, 837-849. [CrossRef]

30. Göpferich, A. Mechanisms of polymer degradation and erosion. Biomaterials 1996, 17, 103-114. [CrossRef]

31. Finer, Y.; Santerre, J.P. The influence of resin chemistry on a dental composite's biodegradation. J. Biomed. Mater. Res. 2004, 69A, 233-246. [CrossRef]

32. Atkinson, J.C.; Diamond, F.; Eichmiller, F.; Selwitz, R.; Jones, G. Stability of bisphenol A, triethylene-glycol dimethacrylate, and bisphenol A dimethacrylate in whole saliva. Dent. Mater. 2002, 18, 128-135. [CrossRef]

33. Hoekman, D. Exploring QSAR fundamentals and applications in chemistry and biology, volume 1. hydrophobic, electronic and steric constants, Volume 2. J. Am. Chem. Soc. 1996, 39, 1189-1190. [CrossRef]

34. Manabe, A.; Kaneko, S.; Numazawa, S.; Itoh, K.; Inoue, M.; Hisamitsu, H.; Sasa, R.; Yoshida, T. Detection of Bisphenol-A in Dental Materials by Gas Chromatography-Mass Spectrometry. Dent. Mater. J. 2000, 19, 75-86. [CrossRef] [PubMed]

35. Tarja Laaninen. New Rules on Bisphenol A in Food Contact Materials. Available online: https://www.europarl.europa.eu/ thinktank/en/document.html?reference=EPRS_ATA(2018)614705 (accessed on 1 November 2021).

36. Ministry of Food and Drug Safety. Standards and Specifications for Appliances, Containers and Packaging [Announcement No 2021-234]. Available online: https://www.mfds.go.kr/brd/m_209/view.do? seq=43478\&srchFr=\&srchTo=\&srchWord=\&srchTp= \&itm_seq_1=0\&itm_seq_2=0\&multi_itm_seq=0\&company_cd=\&company_nm=\&page=1 (accessed on 1 November 2021).

37. Chang Yeob, S.; Woong, K.; Myung Chan, G. Current State of Use and the Risks of Bisphenols: A Minireview. Korean J. Environ. Biol. 2017, 35, 581-594. [CrossRef]

38. Örtengren, U.; Andersson, F.; Elgh, U.; Terselius, B.; Karlsson, S. Influence of pH and storage time on the sorption and solubility behaviour of three composite resin materials. J. Dent. 2001, 29, 35-41. [CrossRef] 